\title{
Not only being compliant, but also being constant in brace wearing improves short-term results: a prospective Thermobrace study
}

\author{
Sabrina Donzelli, Monia Lusini, Salvatore Minnella, Fabio Zaina, Stefano Negrini \\ From 10th International Conference on Conservative Management of Spinal Deformities - SOSORT 2013 \\ Annual Meeting \\ Chicago, IL, USA. 8-11 May 2013
}

\section{Background}

Compliance, together with quality of bracing, have shown to achieve good results in scoliotic patients. However, nothing is known about constant brace wearing $(\mathrm{CBW})$, which means maintaining the same number of hours almost every day. CBW is recommended at each brace prescription, but is it true that being constant will bring the best results?

\section{Purpose}

The goal of this study was to find out if CBW is rewarded with better bracing results in the short term.

\section{Methods}

Prospective controlled cohort study nested into a clinical database started in 2003. On December 31, 2012, out of 11,800 patients in the database, we selected 168 who met the following inclusion criteria: Adolescent Idiopathic Scoliosis, Sforzesco brace prescription 18 to 23 hours/day, at least four months of observation, Thermobrace (TB) adoption and out-of-brace $\mathrm{x}$-ray before treatment. CBW (104 patients) was compared to ficklebrace wearing (FBW: 64): due to the abnormal distribution of TB values, one hour in the inter-quartile range distinguished the two groups. A 6-degree Cobb cut-off was defined to classify results as improved, worsened or stabilized. Patients were also classified for compliance: High (HC: $>95 \%$ of prescription), Middle (MC: $70-94 \%$ ) and Low (LC: $<70 \%$ ). For statistical analysis, chi-square test has been used; the relative risk (RR) of not improvement (i.e.,

* Correspondence: sabrina.donzelli@isico.it

ISICO Italian Scientific Spine Institute, Milan, Italy progression or stabilization only) with $95 \%$ Confidence Interval (IC95) has been calculated as well.

\section{Results}

Males were more frequent in FBW $(78.1 \%$ vs $12.5 \%$ in CBW - $\mathrm{P}<0.0001)$. CBW-HC showed a high percentage of improved and stabilized curves $(44.2 \%$ and $28.8 \%)$ when compared to FBW (10.9\% and $10.9 \%)$. CBW are frequently $\mathrm{HC}, 81.7 \%$ versus $21.8 \%$ in $\mathrm{FBW}(\mathrm{P}<0.0001)$. In both groups, $\mathrm{HC}$ were more frequent in the group of prescription over $22 \mathrm{~h}$ per day, while the severity of scoliosis did not affect compliance or CBW. Without distinctions for compliance, RR in the short-term for FBW was 1.35 (IC95: 0.95-1.93 - P=0.08). FBW-MC/LC, compared to CBW-HC showed a RR of 1.50 (IC95: 1.0$2.3-\mathrm{P}=0.04)$.

\section{Conclusions and discussion}

Wearing a brace rigorously $(\mathrm{HC})$ and constantly (CBW) provides good results, and this remains true in $\mathrm{MC}$. Compliance to prescription is fundamental to a higher probability of achieving good results, but FBW can represent a risk for progression. Future studies should document these data at the end of treatment.

Published: 18 September 2013

\section{References}

1. Katz DE, Durrani AA: Factors that influence outcome in bracing large curves in patients with adolescent idiopathic scoliosis. Spine 2001, 26(21):2354-2361.

2. Brox Jl, Lange JE, Gunderson RB, Steen H: Good brace compliance reduced curve progression and surgical rates in patients with idiopathic scoliosis. Eur Spine J 2012, 21(10):1957-63.

3. Tavernaro M, Pellegrini A, Tessadri F, Zaina F, Zonta A, Negrini S: Team care to cure adolescents with braces (avoiding low quality of life, pain and

C 2013 Donzelli et al; licensee BioMed Central Ltd. This is an Open Access article distributed under the terms of the Creative Commons 
bad compliance): a case-control retrospective study. 2011 SOSORT Award winner. Scoliosis 2012, 7(1):17.

doi:10.1186/1748-7161-8-S2-055

Cite this article as: Donzelli et al: Not only being compliant, but also

being constant in brace wearing improves short-term results: a

prospective Thermobrace study. Scoliosis 2013 8(Suppl 2):055.

Submit your next manuscript to BioMed Central and take full advantage of:

- Convenient online submission

- Thorough peer review

- No space constraints or color figure charges

- Immediate publication on acceptance

- Inclusion in PubMed, CAS, Scopus and Google Scholar

- Research which is freely available for redistribution

Submit your manuscript at www.biomedcentral.com/submit 